\title{
Tribute To Les Emerson
}

\section{INTRODUCTION}

On 1st December, 1985, the Patron of the Victorian Chapter of A.A.S.E., Mr. T. L. W. (Les) Emerson died after a brief illness. This tribute to Les Emerson was submitted by Peter Lea-Wood, former President of the Victorian Chapter and National Secretary of A.A.S.E.

\section{T. L. W. EMERSON - A Personal Tribute}

Thomas Leslie William Emerson, B.A., B. Ed., T.P.T.C., M.A.C.E., O.B.E. was appointed as the Victorian Education Department's first Director of Special Services in 1968 and occupied that position till his retirement in September 1976. He served education for more than 45 years as a teacher, inspector and senior administrator and from 19421945 interrupted his career to serve with RAAF Bomber Command in Europe.

Les Emerson, as he was more popularly known, was a man of vision, an innovator who had the ability to inspire others and who could reduce complicated issues into simple terms. To the writer, his most outstanding personal characteristics were his integrity, his belief in the worth of all people, his courage and determination and his sense of loyalty.

Initiatives that he took included the introduction of revolutionary teaching methods, such as "Initial Teaching Alphabet" and "Words-in-Color"; the establishment of procedures which legitimated the practice of Work Experience activities; the establishment of principals' associations for special school principals; the requirement that all teachers appointed to permanent positions in special education must be suitably qualified; and the establishment and development of the Special Education Units and the Demonstration Units.

While it is not suggested that the original concept of each of these initiatives was born in the mind of Les Emerson (though many were), the fact is that he had the vision to recognise their worth and the courage and determination to make them reality.

In an organisation which is not renowned for direct communication links between top administration and those at the workface, Les Emerson departed from tradition with exceptional results. He was a freqent visitor to special schools and settings, and indeed to all kinds of Special Services establishments. $\mathrm{He}$ was approachable and listened carefully to teachers, principals and parents. Les recognised and addressed by name hundreds of teachers and other officers of his division - a feat unlikely to be equalled by any other divisional director.

The relationships that Les Emerson had with the teachers gave rise to the invitation from the Association of Special Teachers of Victoria for him to become their first and only patron. When that organisation became the Victorian Chapter of AASE that invitation was renewed and, as on the first occasion, accepted.

Les was deeply honoured with the patronage. His respect for special teachers was both genuine and profound. He often described (and in high places too) special teachers as "the most highly professional group of educators in this country". It is not widely recalled that the ASTV in this state, and perhaps this nation, were the first to conduct teacher-generated, teachermanaged residential in-service programs, in their own time and at their own expense. Les Emerson's response was to grant leave and provide for replacement staff where necessary to allow these weekend programs to be increased in length and spread over into the school week. The same philosophy was behind his part in the establishment of the Bachelor of Special Education Course at Monash University and the granting of study leave to so many who undertook the degree.

His term as Director of Special Services was marked by two important government inquiries into the provision of services to disabled students and Les was a prominent, active member of both. The Ministerial Inquiry into Special Education in Victoria produced its report in 1973 and subsequently the parliament passed a bill which came to be known as the "Handicapped Children's Act" which was very much the handiwork of Les Emerson and reflected his views very strongly. Although there is now in place even more progressive legislation, the "Handicapped Children's Act" admitted, for the first time in this state, that government had a responsibility to respond to the needs of disabled students.

The Premier's Committee of Inquiry into Mental Retardation involved Les Emerson in the writing of its detailed report, even into retirement. Its recommendations, produced in 1977 resulted in the establishment of the Mental Retardation Division within the Health Commission.

Les Emerson's sense of loyalty was an outstanding characteristic. He was intensely loyal to his own staff and expected them to respond in kind. Disloyalty was something he could never comprehend and he abhorred it thoroughly. In the infant Special Services Division, most of its branches were headed by people who were strong personalities backed by dedicated followers. It is some measure of the man that people of that calibre bestowed on Les the mantle of leadership; for leadership is not conferred by any others than those who follow and the price they demand is the leader's loyalty to his followers.

It was fitting then that the ASTV executive should establish the T.L.W. Emerson Award which is given annually to a person or persons who have made an 


\title{
Tribute to Les Emerson
}

outstanding contribution to special education in Victoria. It is hoped that this award will continue in the years to come as a tribute to a man who made such significant contribution to the profession.

It was equally appropriate that the approaches to have an award made to Les Emerson in the Honours List should come from the same quarter. When he was installed as an Officer of the Order of the British Empire it was seen by all as a just reward for a very distinguished career.
Although Les Emerson has gone it will be impossible to forget him. He set in train so many projects and activities, he established schools and services and he touched the lives of so many individuals that his life will continue for a long time after his death. We will miss him but in mourning his departure we should also celebrate his life.

Peter L. Lea-Wood

\section{AUSTRALIAN ASSOCIATION OF SPECIAL EDUCATION}

\section{1th National Conference AdELAIDE 3-7 SEPTEMBER 1986}

\section{Responding to Expectations}

\begin{abstract}
Invited keynote speakers will be Professor Richard L. Schiefelbusch, Bureau of Child Research, Unıversity of Kansas, and Dr. Roy Evans, Director of Educational Studies, Roehampton Institute, University of London. The theme 'Responding to Expectations' will be addressed in the areas of
\end{abstract}

PROGRAMME AND SERVICE DEVELOPMENTS

All areas of exceptionality, especially the profoundly and multiply handicapped

INTEGRATION - WHO BENEFITS?

What have we learned from years of integration?

LEARNING DISABILITIES : CONTEXT AND CONSEQUENCE

Literacy, numeracy and the learning disabled. LD. a product of teaching or separate disability?

For Information and Registrations, contact either:

Dr. David Thomas, School of Education, Flinders University, Bedford Park, S.A., 5042

Ph: (08) 2752830

or (08) 2752422

or Mr. Don Rice, Institute for the Study of Learning Difficulties, S.A.C.A.E. - Sturt Sturt Road, Bedford Park, S.A., 5042

Ph: (08) 2755422

THE CONFERENCE WILL BE HOSTED BY THE AUSTRALIAN ASSOCIATION OF SPECIAL EDUCATION (S.A. CHAPTER) IN ASSOCIATION WITH THE INSTITUTE FOR THE STUDY OF LEARNING DIFFICULTIES.

The 1986 (ionference is an official function

of the South Australia 15()th. Inniversary: 